\title{
PENYELESAIAN GUGATAN SEDERHANA DI PENGADILAN (SMALL CLAIM COURT) BERDASARKAN PERATURAN MAHKAMAH AGUNG NOMOR 2 TAHUN 2015
}

\author{
Muhamad Noor \\ Universitas Islam Indonesia Yogyakarta \\ Email:mohammadnoer380@gmail.com
}

\begin{abstract}
A civil dispute is a civil case that occurs for litigants. In practice the parties to the dispute are settled in court. Dispute resolution through a mechanism using several methods. The method has two simple models and a juridical model. This article explores a mechanism of private dispute resolution by small claim court. The Supreme Court of the Republic of Indonesia issued a policy of the Supreme Court Number 2 Year 2005 on mechanism of small claim court. This article is based on normative research which examine implementation of law especially in the case of small claim court. By using theory and principle of civil code procedures; fast, simple and inexpensive, the finding of this article indicates that small claim court becomes a mechanism of dispute resolution quickly, effectively and efficiently through litigation process. The results of this article confirm that the mechanism for the dispute resolution stage with small claim court is resolved with a simple procedure. Small claim court is filed against a case of breach of contract or default and acts against the law with a period of settlement of a small claim resolution no later than 25 (twenty-five) days from the day of the first session court.
\end{abstract}

Keywords: Indonesia Court, Small Claim Court, Private Law

\begin{abstract}
Abstrak
Sengketa perdata adalah suatu perkara perdata yang terjadi bagi para pihak yang berperkara. Praktiknya para pihak yang bersengketa diselesaikan di pengadilan. Penyelesaian sengketa melalui mekanisme menggunakan beberapa metode. Metode memiliki dua model sederhana dan model sesuai yuridis. Artikel ini mengkaji tentang mekanisme penyelesaian sengketa perdata dengan pola gugatan sederhana (small claim court) di pengadilan. Mahkamah Agung Republik Indonesia mengeluarkan Peraturan Mahkamah Agung Nomor 2 Tahun 2015 tentang Tata Cara Penyelesaian Gugatan Sederhana. Tujuan dari artikel ini adalah untuk mengetahui analisis mekanisme penyelesaian sengketa perdata. Tipe penelitian yang digunakan adalah yuridis normatif, mengenai implementasi ketentuan hukum normatif sebagai normayang hidup dalam masyarakat. Dengan menggunakan teori dalam hukum dan prinsip hukum acara perdata yaitu asas cepat, sederhana dan biaya ringan, artikel ini menemukan bahwa penyelesaian gugatan sederhana (small claim court), menjadi mekanisme untuk menyelesaiakan sengketa secara lebih cepat, efisien dan efektif sebagai pola penyelesaian sengketa melalui jalur litigasi bagi para pencari keadilan. Hasil dari
\end{abstract}


artikel ini menegaskan bahwa mekanisme tahapan penyelesaian sengketa dengan pola gugatan sederhana di peradilan diselesaikan dengan tata cara dan pembuktiannya yang sederhana. Gugatan sederhana diajukan terhadap perkara cidera janji atau wanprestasi dan perbuatan melawan hukum dengan jangka waktu penyelesaian gugatan sederhana paling lama 25 (dua puluh lima) hari sejak hari sidang pertama.

Kata Kunci: Pengadilan di Indonesia, gugatan sederhana, hukum perdata

\section{PENDAHULUAN}

Perkembangan transaksi dalam kegiatan bisnis berjumlah ratusan kali perhari. Hal ini tidak menutup kemungkinan terjadinya sengketa diantara para pihak-pihak yang terlibat dalam transaksi bisnis tersebut. Tentunya sengketa yang terjadi menuntut adanya solusi penyelesaian. Semakin cepat, efektif, dan efisien suatu penyelesaian sengketa semakin baik keadaannya untuk kedua belah pihak. Jumlah transaksi berkorelasi positifterhadap jumlah frekuensi sengketanya, artinya semakin banyak transaksi bisnis yang terjadi, maka semakin sering pula terjadi sengketa. Implikasinya, banyak kasus-kasus sengketa yang harus diselesaikan oleh kedua belah pihak yang bersengketa (Jamilah, 2014: 3)). Cara untuk menyelesaikan sengketa bisnis dapat dilakukan melalui dua bentuk pola penyelesaian. Pertama, penyelesaian sengketa menggunakan pola litigasi atau penyelesaian sengketa di muka pengadilan. Kedua, penyelesaian sengketa menggunakan pola non litigasi atau penyelesaian sengketa di luar pengadilan, yakni dengan cara-cara mediasi atau perdamaian (Ali, 2015: 338).

Sistem peradilan di Indonesia diselenggarakan berdasarkan asas sederhana, cepat dan biaya ringan. Sederhana artinya tidak bertele-tele, cepat berarti proses pemeriksaan perkara dilakkan dengan tidak memakan waktu lama. Biaya ringan berarti dalam proses peradilan tidak membutuhkan biaya besar. Pemberlakuan Perma No. 2 tahun 2015 tentang Tata Cara Penyelsaian Gugatan Sederhana tetapi perlu disosialisasikan agar masyarakat yang menyelesaikan sengketanya segera berakhir (Balitbang Hukum dan HAM, 2017: 83). Penyelesaian sengketa bisnis diuatamakan untuk dapat menggunakan pola non litigasi karena prosesnya lebih cepat, efektif, dan efisien serta sangat direkomendasikan bagi kedua belah pihak yang bersengketa. Akan tetapi, jika pola non litigasi tersebut tidak dapat diupayakan bagi kedua belah pihak, maka sebagai solusinya dapat menggunakan pola litigasi. Bentuk litigasi merupakan semata-mata hanya sebagai jalan terakhir (ultimatum remedium) etelah alternatif non litigasi dinilai tidak membuahkan hasil dalam proses penyelesaian sengketa (Margono, 2010: 4).

Proses litigasi salah satu azas hukum acara perdata, yakni azas peradilan sederhana, cepat, dan biaya ringan. Asas sederhana yakni 
penyelenggaraan dari persidangan dilakukan dengan mekanisme yang pasti dan sederhana. Asas cepat bermakna bahwa persidangan diselenggarakan dalam tenggat waktu yang patut. Asas biaya ringan bermakna dalam persidangan tersebut timbul biaya berpekara dan biaya tersebut telah ditetapkan besaran biaya yang layak dan dapat dijangkau oleh berbagai kalangan masyarakat Indonesia (Pratama dan Anand, 2017: 205). Mahkamah Agung Republik Indonesia mengeluarkan Peraturan Mahkamah Agung Nomor 2 Tahun 2015 tentang Tata Cara Penyelesaian Gugatan Sederhana. Perma ini adalah sebuah langkah besar dari Mahkamah Agung untuk mewujudkan penyelesaian perkara sesuai azas cepat, sederhana dan biaya ringan. Perma ini juga diharapkan membantu masyarakat kecil yang tidak mampu yang bersengketa yang nilai sangat kecil dan memakan waktu yang lama bila diselesaikan dipengadilan. Mekanisme dengan small claim court merupakan penyelesaian sengketamelalui pengadilan dengan acara cepat dan sederhana sehingga biaya dapat lebihringan, dengan menggunakan prosedur beracara di luar prosedur dalam menangani perkara perdata biasa, yang diperuntukan bagi perkara perdata dengan nilai gugatan kecil. Melalui mekanisme small claim court, penyelesaian sengketa perdata (bisnis) diharapkan dapat memenuhi asas peradilan cepat, sederhana dan biaya ringan (Fakhriah, 2018).

Urgensi terpenting terbitnya PERMA adalah salah satu cara mengurangi volume perkara di MA dan diadopsi dari sistem peradilan small claim court yang salah satunya diterapkan di London, Inggris. Small claim court adalah sebuah mekanisme penyelesaian perkara secara cepat sehingga yang diperiksa dalam small claim court tentunya adalah perkaraperkara yang sederhana. Dalam Pasal 1 angka 1 PERMA Nomor 2 Tahun 2015 disebutkan Penyelesaian Gugatan Sederhana diartikan sebagai tata cara pemeriksaan di persidangan terhadap gugatan perdata dengan nilai gugatan materil paling banyak Rp 200 juta yang diselesaikan dengan tata cara dan pembuktiannya sederhana.Lebih lanjut PERMA Nomor 2 Tahun 2015 menetapkan kriteria perkara yang diselesaikan dengan mekanisme small claim court adalah perkara cidera janji (wanprestasi) dan atau perbuatan melawan hukum (PMH). PERMA juga mensyaratkan bahwa pihak-pihak penggugat dan tergugat tidak boleh lebih dari satu, kecuali kepentingan hukum yang sama. Dengan demikian, penyelesaian gugatan sederhana (small claim court), menjadi mekanisme untuk menyelesaiakan sengketa secara lebih cepat, efisien dan efektif ketika melalui pola penyelesaian sengketa melalui jalur atau pola litigasi bagi para pencari keadilan. 


\section{METODE PENELITIAN}

Metode penelitian yang digunakan dalam tulisan ini adalah deskriptif analitik. Metode deskripsi dapat diartikan sebagai prosedur pemecahan masalah yang diselidiki dengan menggambarkan keadaan subjek atau objek dalam penelitian. Objek penelitian dapat berupa orang, lembaga, masyarakat atau yang lainnya. Sedangkan analisa penelitian menjadi tolak ukur dalam membentuk objek penelitian. Hal tersebut adalah tentang tata cara atau mekanisme yang digunakan dalam menyelesaikan gugatan sederhana. Kelebihan dari penelitian ini adalah mampu menganalisa isu atau topik yang tidak bisa diukur secara numerik. Adapun metode pendekatan menggunakan pengamatan dalam setting sosial yang natural dan apa adanya.

\section{PEMBAHASAN}

\section{Gugatan Sederhana dan Ruang Lingkupnya}

Gugatan sederhana adalah gugatan dalam bidang hukum perdata yang nilai gugatan materiilnya paling banyak Rp. 200.000.000,- yang diselesaikan dengan tata cara dan pembuktiannya sederhana (simple procedures and evidentiary). Gugatan sederhana menurut PERMA Nomor 2 Tahun 2015 tentang Tata Cara Penyelesaian Gugatan Sederhana diimplementasikan dalam gugatan yang pokok perkaranya (objectum litisnya) adalah perbuatan cidera janji (wanprestasi) dan/atau perbuatan melawan hukum (Mahkamah Agung Republik Indonesia, 2015: 10).

Dalam Pasal 4 PERMA Nomor 2 Tahun 2015 dikemukakan beberapa ketentuan yang harus dipenuhi agar suatu gugatan dapat dikategorikan sebagai gugatan sederhana, yaitu: Pertama, Pihak dalam gugatan berperkara hanya diperbolehkan terdiri atas penggugat dan tergugat. Selanjutnya, masing-masing penggugat dan tergugat hanya boleh terdiri atas satu orang. Dengan demikian, dalam gugatan sederhana tidak diperkenankan adanya kumulasi subjektif. Untuk hal tersebut, maka jika ada dua subjek atau lebih yang berkepentingan terhadap objek yang sama, maka gugatan sederhana harus dipecah (splitting) menjadi dua atau lebih sesuai dengan jumlah subjek yang ada. Kedua, Domisili pihak berperkaraharus berada dalam wilayah hukum Pengadilan Negeri yang menerima perkara tersebut. Hal ini dikarenakan jika salah seorang pihak berdomisili di luar wilayah Pengadilan Negeri yang menerima perkara, maka penyelesaiannya akan memakan waktu lama karena pemanggilan phak berperkara di luar wilayah Pengadilan memakan waktu lama, sementara limit waktu penyelesaian gugatan sederhana adalah 25 hari.

Ketiga, Kehadiran pihak dalam persidangan dikarenakan pemeriksaannya secara cepat, maka dalam gugatan sederhana, pihakpihak berperkara wajib menghadiri sendiri persidangan, sekalipun ia telah menunjuk advokat sebagai kuasa hukumnya. Pemeriksaan langsung 
terhadap principal tidak lain bertujuan agar pemeriksaan lebih cepat dan sederhana. Keempat, Tergugat tidak diketahui tempat tinggalnya, dalam gugatan ternyata pihak tergugat tidak diketahui tempat tinggalnya, maka gugatan tersebut tiak dapat dikategorikan sebagai gugatan sederhana. Hal ini dikarenakan pemanggilan terhadap pihak yang tidak diketahui tempat tinggalnya memerlukan waktu yang cukup lama dan kemungkinan besar limitasi waktu penyelesaian perkara perdata yang ditetapkan (25 hari) tidak dapat terpenuhi.

Implementasi gugatan sederhana menurut PERMA Nomor 2 Tahun 2015 tidak termasuk pada dua bentuk dan jenis perkara, yaitu pertama, perkara-perkara penyelesaian sengketanya dilakukan melalui pengadilan khusus sebagaimana diatur dalam perundang-undangan. Perkara-perkara perdata tertentu menurut beberapa ketentuan dalam perundang-undangan merupakan kewenangan pengadilan khusus. Kedua, Sengketa hak atas tanah merupakan sengketa keperdataan yang pembuktiannya cukup rumit. Selain karena sifat tanah sebagai benda tidak bergerak melingkup berbagai dimensi keperdataan seperti titel hak, pencatatan, pengalihan, dan penjaminan, sering kali dalam praktik ditemukan bahwa membuktikan riwayat pemilikan tanah sangat sulit terlebih jika tanah tersebut dahulunya adalah tanah adat.

Gugatan sederhana atas perbuatan cidera janji (wanprestasi) dan/atau perbuatan melawan hukum merupakan kewenangan dari pengadilan dalam lingkungan peradilan umum. Kewenangan mengadili Pengadilan Negeri yang diatribusi Undang-undang mencakup segala bentuk perkara perdata, kecuali ditentukan oleh Undang-undang bahwa perkara tertentu merupakan kewenangan pengadilan khusus, yaitu pengadilan dalam lingkungan Peradilan Agama, Pengadilan Niaga, dan Pengadilan Hubungan Industrial. Namun demikian, Pengadilan Agama juga dapat menerima, memeriksa dan memutus sengketa dengan pola gugatan sederhana ketika perkara tersebut termasuk dalam kategori gugatan sederhana, khususnya dalam sengketa ekonomi syariah, hibah, zakat, wakaf, infak, sedekah ketika terkait dengan wanprestasi dan perbuatan melawan hukum.

\section{Hukum Acara dan Prosedur Penyelesaian Gugatan Sederhana Berdasarkan PERMA Nomor 2 Tahun 2015}

Penyelesaian gugatan sederhana diwujudkan secara cepat, maka Peraturan Mahkamah Agung Republik Indonesia Nomor 2 Tahun 2015 tentang Tata Cara Penyelesaian Gugatan Sederhana telah menetapkan hukum acara dan prosedur penyelesaian gugatan sederhana sebagai berikut : 
a. Hakim pemeriksa perkara

Prinsip dalam penyelesaian gugatan sederhana adalah persidangan yang dipimpin oleh hakim tunggal. Ketua pengadilan menetapkan hakim tunggal yang akan memeriksa perkara. Hakim tunggal yang ditunjuk selanjutnya diberi kewenangan untuk menilai apakah gugatan tersebut dapat dikategorikan sebagai gugatan sederhana atau tidak.

b. Tahapan penerimaan dan penyelesaian gugatan sederhana

1) Pendaftaran

Tahapan dan prosedur pendaftaran gugatan sederhana di Pengadilan Negeri adalah :

a) Penggugat mendaftarkan langsung gugatannya di Kepaniteraan Pengadilan Negeri

Penggugat dapat langsung mendaftarkan gugatan yang telah dibuat sebelumnya. Jika Penggugat tidak memahami cara membuat gugatan, maka ia dapat mengisi blanko gugatan sederhana yang disediakan di Kepaniteraan Pengadilan. Dalam blanko gugatan, Penggugat mengisi keterangan-keterangan yang diperlukan, yaitu:

(1) Identitas Penggugat dan Tergugat

Identitas mencantumkan hal-hal pokok, yaitu nama lengkap dan alias (bila ada), umur, pekerjaan, dan domisili atau tempat kediaman senyatanya dari Penggugat dan Tergugat.

(2) Penjelasan tentang duduk perkara

Dalam duduk perkara, Penggugat menguraikan kejadian atau peristiwa yang mendasari gugatan (feitelijke gronden), misalnya adanya perjanjian jual beli yang melahirkan hubungan hukum antara Penggugat dan Tergugat pada waktu tertentu dengan objek perjanjian tertentu. Uraian selanjutnya adalah perbuatan yang melahirkan akibat hukum, misalnya Tergugat melakukan cidera janji sehingga menimbulkan kerugian bagi Penggugat.

(3) Tuntutan Penggugat

Pada bagian akhir, Penggugat menguraikan tuntutantuntutannya berdasarkan uraian pada duduk perkara.

b) Melampirkan bukti surat yang telah dilegalisasi

Melampirkan alat bukti sebenarnya dilakukan pada saat persidangan memasuki agenda pembuktian. Namun, untuk kepentingan pemeriksaan gugatan sederhana yang mengutamakan kesederhanaan dan kecepatan dalam beracara, maka Penggugat diwajibkan untuk telah melampirkan buktibukti surat yang diperlukan pada saat mendaftarkan gugatan. 
c) Pemeriksaan kelengkapan gugatan sederhana, pembauaran panjar biaya perkara, dan pencatatan dalam register

Ketika Penggugat mendaftkan gugatannya, Panitera Pengadilan wajib telebih dahulu memeriksa kelengkapan berkas gugatan.Jika ada kekurangan dalam berkas gugatan, maka panitera mengembalikan berkas tersebut kepada Penggugat untuk dilengkapi.Setelah seluruh berkas diang gap lengkap, maka Ketua Pengadilan menetapkan panjar biaya perkara dan melalui Kepaniteraan Pengadilan, Penggugat wajib membayar panjar tesebut. Jika Penggugat adalah pihak yang tidak mampu maka ia dapat mengajukan permohonan berperkara secara cuma-Cuma. Setelah berkas gugatan lengkap dan panjar biaya perkara telah dilunasi oleh Penggugat, maka selanjutnya gugatan didaftarkan dalam buku register khusus gugatan sederhana.

2) Penetapan Hakim

Setelah gugatan sederhana didaftarkan di Kepaniteraan dan tercatat dalam buku register khusus gugatan sederhana, maka Ketua Pengadilan menetapkan Hakim Tunggal yang akan memeriksa perkara. Hakim Tunggal yang ditunjuk selanjutnya akan melakukan pemeriksaan pendahuluan dan jika syarat-syarat gugatan sederhana dipenuhi maka Hakim Tunggal akan memimpin persidangan gugatan sederhana.

3) Penunjukan Panitera Pengganti

Panitera Pengadilan setelah menerima berkas perkara yang telah dilampiri penetapan hakim tunggal, selanjutnya menunjuk Panitera Pengganti.Panitera Pengganti bertugas untuk membantu Hakim dalam memeriksa gugatan sederhana.

4) Pemeriksaan pendahuluan

Kekhasan dalam penyelesaian gugatan sederhana adalah adanya pemeriksaan pendahuluan.Pemeriksaan pendahuluan ini mirip dengan pemeriksaan pendahuluan dalam hukum acara Peradilan Tata Usaha Negara yang disebut dengan dismissal process. Pemeriksaan pendahuluan dilakukan oleh Hakim tunggal (baca: Hakim) yang telah ditetapkan Ketua Pengadilan. Dalam pemeriksaan pendahuluan, hakim meneliti beberapa hal seperti materi gugatan sederhana yang mencakup obyek gugatan dan pihak-pihak yang berperkara. Di samping itu, hakim akan meliti secara seksama apakah pembuktian atas gugatan tersebut sifatnya sederhana atau tidak. Untuk menilai hal ini, maka hakim terlebih dahulu melihat hubungan hukum apa yang terjadi antara pihak berperkara, sejauh mana kompleksitas hubungan hukum tersebut, dan apakah akibat hukumnya hanya menjangkau pihak berperkara 
atau ada pihak lain yang berdampak hukum. Hakim akan melihat pula bukti-bukti surat yang telah dilampirkan saat mendafarkan gugatan sederhana.

5) Penetapan hari sidang

Dari kesimpulan hakim bahwa gugatan tersebut merupakan gugatan sederhana dan pemeriksaaan perkara dapat dilanjutkan, hakim kemudian menetapkan hari sidang pertama untuk pemeriksaan perkara tersebut.Dalam penetapan tersebut ditetapkan hari dan tanggal pelaksanaan sidang serta perintah kepada Jurusita atau Jurusita Pengganti untuk melakukan pemanggilan para pihak-pihak berperkara.

6) Pemanggilan para pihak berperkara

Pemanggilan kepada pihak harus dilaksanakan dengan patut sebagaimana maksud ketentuan Pasal 122 HIR/Pasal 146 R.Bg., yaitu tenggang waktu hari memanggil dengan hari sidang sekurang-kurangnya tiga hari kerja.Jika pada sidang pertama Penggugat tidak datang menghadap persidangan tanpa alasan yang sah, maka gugatan dinyatakan gugur. Jika tergugat tidak datang pada persidangan pertama, maka akan dilakukan pemanggilan kedua secara patut dan jika pada sidang kedua Tergugat tetap tidak hadir tanpa alasan yang patut maka Hakim memutus perkara. Jika Tergugat pernah hadir pada sidang Pertama kemudian tidak hadir lagi pada sidang-sidang berikutnya, maka perkara diperiksa dan diputus secara contradictoir (di luar hadirnya Tergugat).

7) Pemeriksaan dalam persidangan dan perdamaian

Segala hal yang terjadi dalam persidangan dicatat dalam berita acara persidangan.Dalam melaksanakan sidang, Hakim dibantu oleh Panitera untuk mencatat segala hal dalam persidangan.

a) Peran Hakim

Peran Hakim dalam pemeriksaan gugatan sederhana sangat signifikan. Hakim dituntut untuk berperan aktif dalam persidangan dalam menyelenggarakan persidangan yang efektif dan efesien. Jika selama persidangan kedua belah pihak hadir, maka hakim wajib berperan aktif dalam hal-hal berikut (Asnawi, 2016: 697):

(1) Memberikan penjelasan mengenai acara gugatan sederhana secara berimbang kepada pihak-pihak yang berperkara;

(2) Mengupayakan penyelesaian perkara secara damai termasuk menyarankan kepada para pihak untuk melakukan perdamaian di luar sidang;

(3) Membimbing atau memberikan petunjuk yang cukup kepada para pihak dalam pembuktian; 
(4) Menjelaskan upaya hukum apa yang dapat ditempuh oleh para pihak jika keberatan dengan putusan Hakim.

b) Perdamaian

Sama halnya dengan proses acara biasa, dalam pemeriksaan gugatan sederhana, pada persidangan pertama yang dihadiri pihak berperkara maka para pihak akan menempuh upaya perdamaian. Perbedaannya adalah upaya perdamaian dalam acara gugatan sederhana tidak tunduk pada ketentuan dalam PERMA Nomor 1 Tahun 2008 tentang Prosedur Mediasi di Pengadilan.Pada pemeriksaaan gugatan sederhana, Hakim wajib mendamaikan pihak-pihak berperkara.Upaya perdamaian yang dilakukan Hakim harus memperhatikan batas waktu penyelesaian gugatan sederhana, sehingga jika pun harus dilakukan beberapa kali upaya damai, waktu untuk itu tidak menyebabkan penyelesaian perkara nantinya melebihi batas waktu 25 hari.

c) Pembacaan gugatan

Setelah upaya perdamaian tidak tercapai pada sidang pertama, maka pemeriksaan dilakukan dengan pembacaan gugatan penggugat. Dalam pembacaan gugatan dimungkinkan adanya koreksi atas kesalahan ketik atau perubahan-perubahan minor dalam gugatan yang sifatnya tidak mengubah pokok perkara.

d) Jawaban Tergugat

Terhadap gugatan Penggugat, Tergugat dapat mengajukan jawaban secara lisan maupun tertulis.Dalam jawaban, Tergugat tidak boleh mengajukan tuntutan provisi, eksepsi, tuntutan balik (rekonvensi).Dalam pemeriksaan gugatan sederhana tidak diperkenankan adanya intervensi karena hal tersebut jelas menyebabkan pemeriksaan berlangsung lama, lagi pula dalam pemeriksaan pendahuluan Hakim telah meneliti ada tidaknya kaitan pihak ketiga dengan pokok perkara.

8) Pembuktian

Prinsip, cara, batas minimal alat bukti, nilai atau daya bukti alat bukti dalam pembuktian gugatan sederhana sepenuhnya tunduk pada ketentuan mengenai pembuktian dalam hukum acara perdata. Jika gugatan diakui atau tidak dibantah, maka hal tersebut tidak perlu dibuktikan dan secara hukum gugatan Penggugat dianggap telah terbukti.Sebaliknya, jika gugatan dibantah, maka Penggugat wajib membuktikan gugatannya, sementara Tergugat wajib membuktikan bantahannya. Penerapan beban pembuktian dilaksanakan dengan mengacu pada prinsip billijkheid atau kepatutan dalam membebankan pembuktian kepada pihak berperkara. 
9) Putusan

Ketika seluruh proses pemeriksaan dilaksanakan, Hakim mengambil suatu kesimpulan dan menuangkannya dalam putusan yang dibacakan dalam sidang terbuka untuk umum. Setelah pembacaan putusan tersebut, Hakim wajib memberitahukan hakhak para pihak untuk mengajukan keberatan jika tidak menerima putusan tersebut. Saat pembacaan putusan ternyata salah seorang pihak tidak hadir, maka Jurusita atau Jurusita Pengganti diperintahkan untuk menyampaikan putusan kepada pihak yang tidak hadir tersebut selambat-lambatnya 2 (dua) hari setelah putusan dibacakan harus telah diserahkan kepada pihak berperkara.

Perlu dipahami bahwa limitasi atas batasan waktu penyelesaian perkara gugatan sederhana menurut Pasal 5 ayat (3) PERMA No. 2 tahun 2015 adalah 25 (dua puluh lima hari) sejak sidang pertama. Sementara itu, hari yang dimaksud adalah dalam Pasal 1 angka 4 adalah hari kerja. Dengan demikian, limitasi waktu penyelesaian gugatan sederhana adalah 25 (dua puluh lima) hari kerja sejak sidang pertama.

\section{Upaya Hukum Terhadap Putusan Gugatan Sederhana}

Upaya hukum terhadap putusan gugatan sederhana adalah keberatan. Keberatan diajukan oleh pihak yang tidak puas dengan putusan Pengadilan kepada ketua Pengadilan yang memutus perkara tersebut. Keberatan diajukan dengan suatu akta pernyataan keberatan yang ditandatangani pengaju diahadapan Panitera Pengadilan.Dalam mengajukan keberatan, pihak pengaju harus mencantumkan alasan-alasan keberatannya (Asnawi, 2016: 698).

Tenggang waktu mengajukan keberatan terhadap putusan gugatan sederhana adalah 7 (tujuh) hari kerja setelah putusan diucapkan atau setelah pemberitahuan putusan disampaikan kepada pihak yang mengajukan keberatan. Jika pemohon keberatan tidak memahami cara membuat permohonan keberatan, maka pemohon dapat mengisi blanko permohonan keberatan yang disediakan Kepaniteraan Pengadilan. Dalam hal keberatan diajukan setelah lewat tenggang waktu yang disediakan, maka keberatan tidak dapat diterima yang dinyatakan dalam suatu penetapan ketua pengadilan berdasarkan surat keterangan dari panitera.

Setelah seluruh berkas permohonan keberatan lengkap dan telah didaftarkan dalam register yang disediakan, maka akta pernyataan keberatan dan memori keberatan disampaikan kepada pihak lawan (termohon keberatan) dalam tenggang waktu 3 (tiga) hari kerja setelah sejak permohonan diterima Pengadilan. Pihak lawan yang telah menerima pemberitahuan tersebut dapat mengajukan kontra memori keberatan 
selambat-lambatnya 3 (tiga) hari kerja setelah pemberitahuan keberatan diterima (Asnawi, 2016: 698). Pemeriksaan keberatan dilakukan oleh Majelis Hakim (terdiri atas tiga orang hakim) yang ditetapkan ketua pengadilan.Pnetapan Majelis Hakim pemeriksa keberatan dilakukan selambat-lambatnya 1 hari kerja setelah permohonan keberatan dinyatakan lengkap.Majelis Hakim dalam permohonan keberatan dipimpin oleh Hakim senior dan beranggotakan dua orang hakim junior.

Pada pemeriksaan kebeartan, tidak diperkenankann melakukan pemeriksaan tmabahan, artinya pemeriksaan tidak lagi dilakukan secara langsung terhadap pihak-pihak berperkara. Pemeriksaan keberatan hanya melingkupi pemeriksaan berkas-berkas perkara yang mencakup tiga hal, yaitu putusan dan berkas gugatan sederhana, Permohonan keberatan dan memori keberatan, Kontra memori keberatan. Seperti halnya dalam pemeriksaan gugatan sederhana yang memiliki limitasi waktu, pemeriksaan keberatan juga dibatasi waktunya, yaitu selambat-lambatnya 7 hari kerja sejak tanggal penetapan majelis hakim pemeriksa permohonan keberatan.

Putusan permohonan keberatan yang diucapkan dalm sidang terbuka untuk umum harus disampaikan kepada pihak-pihak yang berperkara. Penyampaian dimaksud harus dilakukan selambat-lambatnya 3 hari kerja sejak putusan diucapkan.sejak disampaikannya putusan kepada pihak-pihak berperkara, maka sejak saat itu pula putusan permohonan keberatan memiliki kekuatan hukum tetap. Putusan keberatan sifatnya final dan mengikat sehingga tidak tersedia upaya hukum banding, kasasi, dan peninjauan kembali. Terhadap eksekusi atau pelaksanaan putusan dalam perkara gugatan sederhana dilakukan terhadap putusan gugatan sederhana yang tidak diajukan keberatan atau terhadap putusan keberatan. Tegasnya, eksekusi diterapkan pada putusan yang telah memiliki kekuatan hukum tetap. Pelaksanaan putusan dalam gugatan sederhana menurut prinsipnya dilaksanakan secara sukarela, atau apabila tidak dilaksanakan secara sukareala maka dapat dilaksanakan melalui lembaga eksekusi. Cara atau prosedur eksekusi putusan gugatan sederhana mengacu pada prosedur eksekusi sebagaimana diatur dalam hukum acara perdata yang terdapat HIR, R.Bg maupun sebagian ketentuan dalam $\mathrm{Rv}$ yang masih dipakai dalam praktik eksekusi perdata. 


\section{SIMPULAN}

Penerapat gugatan sederhana dalam pelaksanaannya memberikan kemudahan bagi masyarakat yang sedang berperkara dipengadilan Negeri dengan lebih cepat dari pada gugatan biasanya. Hal tersebut menunjukan jarak dari dua jenis gugatan dipengadilan. Gugatan sederhana merupakan gugatan perdata dengan nilai gugatan materiil paling banyak Rp. 200.000.000,- (dua ratus juta rupiah) yang diseslesaikan dengan tata cara dan pembuktian yang sederhana. Penyelesaian sengketa dengan gugatan sederhana hanya bisa digunakan untuk perkara inkar janji (wanprestasi) dan perbuatan melawan hukum. Perkara wanprestasi merupakan perkara yang timbul akibat tidak dipenuhinya suatu perjanjian, baik secara tertulis ataupun tidak tertulis. Perkara perbuatan melawan hukum adalah perkara yang timbul akibat dirugikannya satu pihak karena tindakan pihak lain dan tidak ada perjanjian sebelumnya. Adapun yang tidak termasuk dalam gugatan sederhana adalah perkara yang penyelesaia sengketanya dilakukan melalui pengadilan khusus dan sengketa tanah.

Undang-Undang Nomor 7 Tahun 1989 sebagaimana telah dirubah dengan Undang-Undang Nomor 3 Tahun 2006 tentang Peradilan Agama telah memberi kewenangan kepada Pengadilan Agama untuk dapat memeriksa dan memutus perkara ekonomi syariah, dimana didalamnya juga ada persoalan penuntutan hak. Mengingat bidang ekonomi syariah yang begitu luas dan berkembang pesat, sehingga potensi kasus di bidang peradilan agama akan sangat banyak. Gugatan wanprestasi yang timbul dari akad-akad syariah yang diajukan oleh para pihak kepada Pengadilan Agama sebagai bagian kompetensi absolut, sehingga Peraturan Mahkamah Agung Nomor 2 Tahun 2015 tentang Tata Cara Penyelesaian Gugatan Sederhana harus mencakup small claim court di lingkungan peradilan agama. 


\section{DAFTAR PUSTAKA}

Ali, Achmad. Menguak Tabir Hukum. Jakarta : Kencana, 2015.

Balitibang Hukum dan HAM, Hasil Penelitian "Penerapan Mekanisme Smaal Calim Court dalam Penegakan Hukum di Indonesia", Balitbang Hukum dan HAM, 2017.

Balitbang Hukum dan HAM, Hasil Penelitian. Penentuan Kreteri Desa/Kelurahan sadar Hukum di Indonesia. Balitbang Hukum dan HAM 2017.

Fakhriah, EfaLaela, Eksistensi Small Claim Court dalam Mewujudkan Tercapainya Peradilan Sederhana, Cepat, danBiayaRingan, Jurnal Mimbar Hukum -repository.unpad.ac.id.

Ferevaldy, Adisti Pratama dan Ghansham Anand, Kedudukan Hakim DalamGugatanSederhana (Small Claim Court), JurnalHukumAcaraPerdata ADHAPER, Vol. 3 No. 2, Juli-Desember 2017.

Huda, Choirul, Karya Ilmiah. Penerapan Smaal Calim Court dalam Perspektif Hukum Pidana di Indonesia. BPHN 2013.

Jamilah, Fitrotin, SHI, MHI, Strategi Penyelesaian Sengketa Bisnis, Jakarta : Pustaka Yustisia, 2014.

Margono, Suyud, Penyelesaian Sengketa Bisnis,Bogor : Ghalia Indonesia, 2010.

M. Natsir, Asnawi. 2016. Hukum Acara Perdata. Yogyakarta: UII Press.

Mahkamah Agung Republik Indonesia. Buku Saku Gugatan Sederhana, Jakarta: Pusat Studi Hukum dan Kebijakan Indonesia, 2015.

Naskah, Akademik, RUU Kitab Undang-undang Hukum Acara Perdata, BPHN 2015.

Sagama, Suwardi, Analisis Konsep Keadilan, Kepastian dan Kemanfaatan Dalam Penelolaan Lingkungan Mazahib, Vol XV, Nomor 1 Juni 2016

\section{Peraturan Perundang-Undangan}

Undang-Undang Nomor 48 tahun 2009 tentang Kekuasaan Kehakiman

Undang-Undang Nomor 30 Tahun 2000 tentang Rahasia Dagang

Undang-Undang Nomor 37 tahun 2004 tentang kepailitan dan Penundaan Kewajiban Pembayaran Hutang

Peraturan Mahkamah Agung Republik Indonesia No. 2 Tahun 2015 TentangTata Cara Penyelesaian Gugatan Sederhana.

Peraturan Mahkaman Agung Nomor 14 tahun 2016 tentang Penyelesaian Perkara Ekonomi Syariah 
Muhamad Noor

Halaman ini sengaja dikosongkan 